\title{
Diplomasi Publik Korea Selatan sebagai Kekuatan Menengah di Bawah Kepresidenan Moon Jae In
}

\author{
Tasha Regina Adriana \\ 2015330183
}

Mahasiswa Ilmu Hubungan Internasional, Fakultas Ilmu Sosial dan Ilmu Politik

Universitas Katolik Parahyangan

\begin{abstract}
Abstrak
In 2016, the people of South Korea jointly voiced their anger after the corruption committed by Park Geun-Hye and her aide was revealed. National Assembly then voted to impeach Park Geun-Hye, resulting her departure from her post on March 10, 2017. Subsequently, Moon Jae-In succeeded her position as president in May 2017. A year in the office, his administration saw how the scandal that involved the previous president could bring an adverse impact on South Korea's image and as well as jeopardize its position as a middle power. Under the presidency of Moon Jae-In, South Korea moves to use soft power and public diplomacy as a strategy to restore its image. This paper will discuss the strategy of Moon Jae-In's administration in using both soft power and public diplomacy to maintain its position as a middle power. Public diplomacy approach will be used to analyze how Moon Jae-In strategizes. At the end of the writing, there will be conclusions that discuss how the strategy has gradually brought an impact on South Korea in the eyes of the world.
\end{abstract}

Keywords: South Korea, Moon Jae-In, Public Diplomacy, Soft Power, Middle Power

\section{Pendahuluan}

Pada tahun 2013, Park Geun-Hye yang resmi menjabat sebagai Presiden Korea Selatan menjadikan presiden perempuan pertama dalam sejarah negeri ginseng tersebut. Seperti para presiden sebelumnya, Korea Selatan di bawah kepemimpinan Park berusaha untuk menjalin hubungan yang baik dengan Amerika Serikat. Selain itu, Park juga mengharapkan perdamaian di Semenanjung Korea, yaitu dengan cara menjalankan Korean Peninsula Trust-Building Process antara Korea Selatan dan Korea Utara. Komitmen Park dalam menciptakan perdamaian ditunjukkan melalui reaksinya terhadap provokasi yang dilakukan oleh Korea Utara mengenai penembakan rudal jarak jauh, yaitu mempertahankan posisi Korea

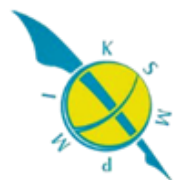


Selatan yang tidak akan menyerah terhadap provokasi dan mengedepankan koordinasi langsung terkait kebijakan dengan melibatkan kekuatan besar. ${ }^{1}$

Namun, masyarakat Korea Selatan harus menerima kenyataan pahit karena presiden perempuan pertama yang sebelumnya dianggap dapat memberikan perubahan besar, ternyata melakukan korupsi yang telah merugikan negara. Kasus ini juga melibatkan banyak konglomerat di Korea Selatan. Respons masyarakat terhadap kasus ini sangat masif, sehingga terdapat protes besar yang terjadi dalam kurun waktu empat bulan, yaitu dari November 2016 hingga Maret 2017. ${ }^{2}$ Skandal ini mengakibatkan Park turun dari jabatannya sebagai presiden setelah Majelis Nasional Korea Selatan memutuskan pendakwaan terhadapnya.

Tidak lama setelah Park meninggalkan posisinya sebagai kepala negara, pemilihan presiden kembali dilakukan. Hasil pemilihan dimenangkan oleh Moon Jae-In yang dulu menjadi kandidat lawan dari Park Geun-Hye pada pemilihan presiden tahun 2012. Moon resmi menjabat pada Mei 2017 dan memiliki tanggung jawab untuk memimpin Korea Selatan selama lima tahun ke depan. Namun, Moon dihadapkan dengan banyak tantangan untuk mengembalikan citra pemerintah di hadapan rakyatnya dan citra Korea Selatan sendiri di tingkat global.

Dunia internasional melihat kemungkinan terjadinya ketidakstabilan dikarenakan kondisi politik yang terjadi di Korea Selatan, terutama terkait dengan citranya sebagai negara korup. Hal ini kemudian memunculkan suatu permasalahan bagi Korea Selatan sebagai salah satu negara yang dianggap masuk ke dalam kategori kekuatan tengah atau yang lebih jelasnya dapat dikatakan merupakan negara yang memiliki pengaruh yang cukup dalam politik internasional. Moon yang kini menjadi nakhoda bagi Korea Selatan untuk tetap mampu berlayar, berusaha untuk bisa menyusun strategi yang diharapkan dapat memulihkan citra Korea

\footnotetext{
${ }^{1}$ Bruce Klingner, The U.S. Should Support New South Korean President's Approach to North Korea, https://www.heritage.org/asia/report/the-us-should-support-new-south-koreanpresidents-approach-north-korea (diakses pada16 April 2018)

2 BBC News, South Korea's Presidential Scandal, http://www.bbc.com/news/world-asia37971085 (diakses pada 16 April 2018)
} 
Selatan di hadapan dunia, yaitu dengan menggunakan diplomasi publik dan juga soft power.

\section{Kerangka Teori}

Masih terdapat banyak perdebatan mengenai konsep dari diplomasi publik. Namun pada dasarnya konsep ini dapat dijelaskan sebagai upaya untuk memberikan pengaruh kepada publik internasional demi kepentingan nasional suatu negara. Dalam tulisan Nicholas J. Cull, ia menjelaskan deskripsi yang disampaikan oleh Edmund Gullion mengenai bagaimana diplomasi publik merupakan suatu hal yang berkaitan dengan sikap publik terhadap suatu pelaksanaan kebijakan luar negeri. Hal ini mencakup dimensi hubungan internasional di luar diplomasi dalam bentuk tradisional, yaitu opini publik dari negara lain, interaksi dari kelompok-kelompok swasta dan kepentingan dalam satu negara dengan negara lain, pelaporan urusan luar negeri dan dampaknya terhadap kebijakan, komunikasi antara mereka yang bekerja di bidang komunikasi, baik sebagai diplomat atau koresponden asing, dan proses komunikasi antar budaya. ${ }^{3}$

Diplomasi publik juga sering dikaitkan dengan propaganda karena memiliki tujuan untuk mempengarungi opini publik. Namun pada dasarnya diplomasi publik memiliki tujuan utama untuk meningkatkan pengetahuan mengenai nilai-nilai dari suatu negara seperti kebijakan dan budaya, membangun hubungan yang stabil antarnegara, serta menciptakan citra positif mengenai negara. Lebih jelasnya John Robert Kelly membagi pendekatan yang digunakan oleh diplomasi publik menjadi tiga, yaitu informasi, pengaruh, dan keterlibatan. Informasi menggunakan cara komunikasi yang terbuka dan transparan, serta dapat dilakukan dalam jangka waktu yang pendek atau pun panjang. Sedangkan untuk membentuk suatu pengaruh,

\footnotetext{
${ }^{3}$ Nicholas J. Cull, "Public Diplomacy" Before Gullion: The Evolution of A Phrase, USC Center on Public Diplomacy, https://uscpublicdiplomacy.org/blog/public-diplomacy-gullionevolution-phrase
} 
bentuk komunikasi yang dilakukan bersifat seperti propaganda karena diperlukan cara yang agresif untuk mendekatkan target dengan suatu opini. ${ }^{4}$

Secara singkat, diplomasi publik mengutamakan soft power sebagai instrumennya. Berdasarkan definisi Joseph Nye, soft power berarti membuat orang lain untuk menginginkan hasil yang anda inginkan. Maka unsur utama dalam menggunakan soft power adalah daya tarik dan persuasi dan sumber daya dari soft power merupakan hal-hal seperti ide, citra, simbol, diskursus, budaya, dan adat istiadat. ${ }^{5}$ Oleh karena itu, untuk menarik minat dari publik internasional terkait dengan kepentingan, negara harus mampu untuk mendorong soft power yang dimilikinya.

\section{Pembahasan}

Korea Selatan melihat pentingnya diplomasi publik untuk menciptakan citra yang baik bagi negaranya. Melalui situs milik Kementerian Luar Negeri Korea Selatan, terdapat bagian khusus untuk menjelaskan mengenai diplomasi publik, dimana kebijakan luar negeri saat ini bukan hanya meliputi aktor pemerintah, tetapi termasuk juga masyarakat dan aktor non-pemerintah lainnya. Dijelaskan pula bahwa aset negara bukan hanya berupa kekuatan dalam militer dan ekonomi, tetapi juga aset lain seperti budaya, nilai-nilai, dan citra nasional. ${ }^{6}$ Sehingga hal inilah yang menjadi fokus bagi pemerintah Korea Selatan dalam melakukan hubungan internasional, yaitu mendorong aspek-aspek yang menarik minat publik internasional terhadap negaranya dengan menggunakan soft power.

\footnotetext{
${ }^{4}$ Iryna Misyuk, Propaganda and Public Diplomacy: the Problem of Differentiation,

${ }^{5}$ Joseph S. Nye, JR., Soft Power, Foreign Policy, hal. 167

6 Kementerian Luar Negeri Korea Selatan, Overview, http://www.mofa.go.kr/eng/wpge/m_5664/contents.do (16 April 2018)
} 


\section{Korea's First Basic Plan on Public Diplomacy}

Salah satu contoh nyata bagi Korea Selatan dalam menjalankan diplomasi publik adalah terbentuknya Korea's First Basic Plan on Public Diplomacy yang menjadi dasar atau petunjuk bagi pemerintahan Moon Jae-In dalam menjalankan diplomasi publik untuk periode 2017-2021. Ini menjadi tindakan konkret pertama yang dilakukan oleh Korea Selatan terkait dengan diplomasi publik. Terdapat empat tujuan utama dari rencana ini: meningkatkan status dan citra Korea Selatan menggunakan budaya, menyebarkan informasi yang akurat tentang Korea, membangun lingkungan yang ramah dan strategis untuk kebijakan Korea, serta memberdayakan dan mendorong kolaborasi di antara agen diplomasi publik. ${ }^{7}$

Komite untuk diplomasi publik dibentuk pada tahun 2017 sebagai penanggung jawab dari berjalannya rencana ini, dimana pengurusnya berasal dari berbagai sektor seperti wakil presiden Kakao Corp., profesor bidang seni dan kebudayaan, dan anggota dari pemerintah. Dalam menjalankan rencana ini, para anggota komite membahas cara-cara untuk meningkatkan kerja sama di antara instansi pemerintah, memanfaatkan kemampuan diplomasi publik dari sektor swasta, dan meningkatkan kesadaran masyarakat dan konsensus sosial mengenai diplomasi publik. ${ }^{8}$ Hal ini menunjukkan bahwa diplomasi publik tidak dapat berjalan ketika hanya negara yang berperan sebagai aktor, sehingga diperlukan bantuan dari sektor swasta. Selain itu terlihat pula bagaimana masyarakat memiliki peran yang penting, karena respons dari masyarakat dapat mempengaruhi jalannya diplomasi publik.

\footnotetext{
${ }^{7}$ Kadir Ayhan, Korea's Soft Power and Public Diplomacy Under Moon Jae-In Administration: A Window of Opportunity, Korea's Soft Power and Public Diplomacy, hal. 17

${ }^{8}$ Kementerian Luar Negeri Korea Selatan, First Meeting of Public Diplomacy Committee to Take Place in Efforts to Carry out Government-wide Public Diplomacy Activities in Integrated and Systematic Manner, http://www.mofa.go.kr/eng/brd/m_5665/view.do?seq=318945\&srchFr=\&srchTo=\&srchW ord=\&srchTp=\&multi_itm_seq=0\&itm_seq_1=0\&itm_seq_2=0\&company_cd=\&company_n $\mathrm{m}=$ \&page $=3 \&$ titleNm $=($ diakses pada 21 April 2018)
}

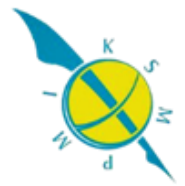


Sejauh yang telah berjalan hingga saat ini, melalui situs Kementerian Luar Negeri Korea Selatan, terdapat berbagai macam festival yang bertujuan untuk mengenalkan budaya. Seluruh kegiatan yang berkaitan dengan pengenalan budaya seperti festival kesenian, kuliner, musik, pendidikan, dan olahraga diliput dan dapat dibaca pada bagian kegiatan diplomasi publik. Partisipasi dari masyarakat memiliki peran yang besar dalam festival-festival tersebut. Selain itu, Korean Wave yang sudah sejak lama berperan dalam penyebaran budaya pop yang dipercayai masih efektif dan kini juga menjadi salah satu bagian dari rencana diplomasi publik, serta kini pengaruhnya telah mencapai luar Asia.

\section{Olimpiade Musim Dingin Pyeongchang 2018}

Memasuki tahun 2018, Pyeongchang menjadi tuan rumah dari Olimpiade Musim Dingin. Ajang ini menjadi kesempatan bagi Korea Selatan untuk menjalankan diplomasinya melalui kegiatan olahraga. Selain itu, Korea Selatan juga memiliki kesempatan untuk menunjukkan eksistensinya sebagai negara yang maju dan memiliki pengaruh yang besar sebagai tuan rumah. Dapat dikatakan, untuk menjadi tuan rumah dari ajang olahraga skala internasional seperti Olimpiade Musim Dingin, kemampuan finansial suatu negara diperlukan untuk dapat menjalankan fungsinya sebagai tuan rumah. ${ }^{9}$ Melalui ajang ini, Korea Selatan dapat menunjukkan dirinya sebagai negara kekuatan menengah yang mapan dalam bidang ekonomi, serta secara bersamaan menjalankan diplomasi publik yang menjadi aspek terpenting dari kebijakan luar negerinya saat ini.

Melihat dari apa yang berjalan selama olimpiade berlangsung, Korea Selatan mendapatkan sorotan atas penampilan yang memukau dan memberikan suatu peninggalan yang memiliki dampak baik bagi citranya. Komite dari Olimpiade Musim Dingin Pyeongchang 2018 bekerja sama dengan Kementerian

\footnotetext{
${ }^{9}$ Jennifer Chan, More Than Just A Game: The Soft Power Politics of Sports and the 2018 Olympic Games, The McGill International Review, https://www.mironline.ca/just-gamesoft-power-politics-sports-2018-olympic-games/ (diakses 23 April 2018)
} 
Pendidikan Korea Selatan untuk meningkatkan pengetahuan mengenai olahraga, hal ini untuk mendorong partisipasi generasi muda dalam kegiatan olahraga seperti olimpiade musim dingin. Selain itu, dalam perancangan kegiatan ini, komite olimpiade memperhatikan dampak lingkungan, ekonomi, dan sosial dari kegiatan yang dilaksanakan. Pembangunan yang dilakukan bersifat berkelanjutan dan ramah lingkungan seperti menggunakan energi terbaruan, infrastruktur ramah lingkungan, dan mengurangi emisi gas rumah kaca. Hal ini mendapatkan respons yang positif dari Badan Program Pembangunan PBB. ${ }^{10}$

\section{Kesimpulan}

Korea Selatan yang memiliki kekhawatiran akan citranya yang terlihat buruk akibat skandal besar oleh Park Geun-Hye kini dapat kembali berdiri dengan caranya sendiri di bawah kepemimpinan Moon Jae-In. Pemerintahan Moon lebih terbuka terhadap masyarakatnya dengan mendorong partisipasi publik terhadap kebijakan dan praktik diplomasinya, berbeda dengan kepemimpinan masa Park yang sering mendapatkan kritik karena cenderung tertutup dan lebih terfokus pada peran negara dan pemerintah. Moon mengambil segala kesempatan yang ada untuk menunjukkan posisi Korea Selatan di tingkat internasional sebagai negara kekuatan menengah. Mulai dari pembentukan Korea's First Basic Plan on Public Diplomacy yang berlaku sebagai fondasi dari diplomasi publik, hingga unjuk kemapanan diri dalam ajang Olimpiade Musim Dingin 2018 dilakukan agar Korea Selatan dapat menyebarkan nilai-nilainya sebagai bentuk dari diplomasi. Setahun setelah menjabat, upaya Moon Jae-In untuk menguatkan posisinya sebagai negara kekuatan menengah melalui diplomasi publik dapat dikatakan berhasil dengan terciptanya rencana yang konkret serta meningkatkan partisipasi dari masyarakat baik domestik maupun internasional dan aktor non-negara lainnya.

${ }^{10}$ Olympics, Pyeongchang Olympic Winter Games Create Legacy of Environmental and Social Good, https://www.olympic.org/news/pyeongchang-olympic-winter-games-createlegacy-of-environmental-and-social-good (diakses pada 23 April 2018)

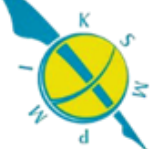

